\title{
INFLUENCE OF NEWSPAPER FRAMING OF COVID-19 PANDEMIC ON READERS' PERCEPTION OF THE VIRUS
}

\author{
Igboeli Chinedu C. \\ Department of Mass Communication \\ Chukwuemeka Odumegwu Ojukwu \\ University Igbariam Campus \\ igboelichinedu@yahoo.com
}

08036807620

\author{
Ezebuenyi Ephraim Ejimnkeonye \\ Department of Mass Communication \\ Nnamdi Azikiwe University, Awka \\ ee.ezebuenyi@unizik.edu.ng \\ 08037344823
}

\begin{abstract}
This study investigated the influence of newspaper framing of Covid-19 pandemic on readers' perception of the virus. The thrust of the study was to ascertain whether the way newspapers select, package and present news stories on the novel Coronavirus affected the way readers of Daily Sun, Vanguard and National Light newspapers in Awka Metropolis view the virus. Specific objectives of the study are among others to: access the patterns of frames used in reporting stories on Covid-19; ascertain respondents' frequency of exposure to newspaper reports on COVID19; know whether the way newspapers report COVID-19 pandemic creates the desired awareness against the spread of the virus; ascertain respondents' perception of newspaper reportage of COVID-19; find out whether the way newspapers select, package and present (frame) stories on COVID-19 influenced respondents' views about the virus. The study was anchored on agenda setting theory. The mixed research design was adopted in carrying out the study. This entails using both the survey and content analysis methods. For the survey method, 386 respondents were selected from the projected population of Awka Metropolis. For the content analysis method, 264 editions were randomly selected from the three select newspapers Findings from the study revealed among others that: seven patterns of frames were used in reporting stories on Covid-19 by the three select newspapers within the period of the study; a more than two-thirds majority of the respondents had high exposure to newspaper reports of COVID-19; majority of the respondents accede that the way newspapers report stories on COVID-19 creates awareness against its spread; majority of the respondents had positive perception on newspaper reportage of COVID-19 and finally, majority of the respondents accede that the way newspapers report COVID-19 influenced the way they view the virus. The study concludes among others that way the media frame issues has the ability to influence audience perception of a particular event and that selection and packaging of the novel Coronavirus enjoys positive reactions in the media. The study recommends among others that: that the Nigerian press should endeavour to select appropriate news angles in reporting public health stories to stem the tendencies of creating rumours and misinformation. This also has the benefit of causing the polity to trust the media in their interpretations of health situations.
\end{abstract}

Keywords: Influence; Framing; Newspapers; COVID-19; Readers; Awka Metropolis;

\section{INTRODUCTION}

The Nigerian newspapers have played a very significant role in achieving a responsible and responsive government by being vocal about the social, economic, political, as well as health issues in Nigeria (Fatusi \& Jimoh, 2006 cited in Ezebuenyi, 2018). Just like other nations, Nigeria has a state-owned news agency called the News Agency of Nigeria (NAN) from which some Nigerian newspapers usually obtain their daily raw news. Prominent among these newspapers are The Guardian, Vanguard, This Day, Punch, Independent, Authority, 
Doi:doi.org/10.47851/naujocommed.v2i1.112

Daily Sun, and National Light newspapers. The Daily Sun, Vanguard and National Light newspapers are the primary focus of this study. Direct reporting is also largely practised by Nigerian media with Nigerian newspapers reporting home and abroad first-hand news. They also monitor core health indicators for other areas of public health that help explain progress in the achievement of specific goals at country level. These include immunization reportage for new antigens, prevalence of risk factors for non-communicable diseases, effectiveness of interventions against these diseases, and impoverishment of households through health payments.

That the mass media can stem or reduce the spread of virus infection is no more in doubt. This according to Ezebuenyi et al. (2020) is achievable through massive campaigns enmeshed in creating the desired awareness. The mass media leverage their agenda- setting function to expose health issues by regular reportage of the issues in the society. This approach has the grandness of attracting people's attention to their health. The way the media reports issues, differs from one content to the other. This variation in contents is also witnessed in terms of the methods, patterns and reasons for the reportage; the impact expected of the reports; and the effects of the reports on the people (Adelakun and Hamedi, 2017). These observed differences in media reportage of issues are determined by factors including the issues involved; the motives and objectives of the media; the interests of the people; each constitutes a pulling force that determines the outcome and influence.

The mass media have the ability to focus attention to some issues while ignoring others. In the views of Weaver, McCombs and Shaw (2004), there is a correlation between degree of salience given to issues the media and the priorities of the people. However, given the level of salience of some issues in the society, the media will be duty bound to highlight them without delay (Huang, 2010). The present Coronavirus outbreak which magnitude is of international concerns is a typical example of such issues. It is therefore the social responsibility function of the media to report health issues in the society. This function of being socially responsible makes the media forerunner of development in the society.

Public health status in Nigeria as well as the role that the mass media play in creating awareness, highlighting health issues and mobilizing Nigerians for healthy living do not correspond with each other. The reason may be that the media's efforts to remain in business which makes them compete for market share for enhanced profits constitute pulling force on how the media report health messages (Cornelissen et al., 2008)

The news angles emphasised are important because they constitute a unique persuasive proposition as they become noticeable, meaningful and memorable to audiences and as a result influence public health decisions (Ezebuenyi, 2018). Some aspects of the information, in addition to expressing the functions which the media play in the development of the health sector also pay much attention between the benefits accruable and social responsibility function of the mass media in times of health problems. Thinking about the challenges of the media position in times of health problems becomes an unanswered puzzle with its answer embedded in the contents of media health news or information.

\section{STATEMENT OF THE PROBLEM}

A look at empirical studies on news coverage of disasters, outbreak of diseases, epidemics, health issues etc., in Nigerian newspapers revealed that the categories constantly examined were prominence, depth of coverage, direction and frequency (Nwammuo, Edegoh and Iwok 
2015; Abubarkre, 2015; Okoro and Odoemelam, 2013). This, no doubt limits the categories that could enhance a more robust and broad based attempt at dissecting media contents and highlighting their importance to the readers. Also, this limited scope makes it difficult to examine other categories which may help in revealing the function of the media in selecting, interpreting and communicating perceived reality - a function which Goffman (1974) cited in Nwabueze and Ezebuenyi (2019) termed 'framing'. Content analysis as a research method has over time represented a style utilized by scholars to evaluate the patterns of media presentation of news of which framing is a key part of it. A lack of studies on the framing of the novel Coronavirus has created a lacuna in the understanding of whether the news media create enough awareness and influence public perception of the virus. Therefore, there exists a gap-in-knowledge which this present study seeks to fill.

This study, therefore, sets out to analyse the framing patterns of the novel Coronavirus reports in some selected newspapers in Nigeria, to uncover the public understanding of the disease and its short- and long-term effects, what sources of information, and frames were used in the coverage of the disease outbreaks, and also how, what and why decisions were made regarding the disease by key players involved in the issue which includes the government, industries representative, consumers and commerce.

\section{OBJECTIVES OF THE STUDY}

The main objective of the study is to investigate the reactions of newspaper reportage of Covid-19 pandemic by Daily Sun, Vanguard National Light newspapers. Specifically, the study evaluated the following objectives:

1. Assess respondents' frequency of exposure to newspaper reports on COVID-19 pandemic.

2. Ascertain respondents' perception of newspaper reportage of COVID-19 pandemic.

3. Find out whether the way newspapers select, package and present stories on COVID19 pandemic influence respondents' views about the virus.

\section{LITERATURE REVIEW}

\section{Overview of the Primary Functions of the Mass Media in Human Society}

Generally, the mass media anywhere in the world have the primary role to inform, educate, persuade, mobilise and entertain the audience. These roles, which are synonymous with the social responsibility roles of the media, have also been identified as traditional roles the media play in every human society from time to time. Communication is germane for any meaningful development to be attained. It is difficult if not impossible for any human activity to be attained without being explored via communication (Ottah, 2015).

To communicate is to pass information from one person to another. This can take place in various forms and means. Irrespective of the forms or means through which communication takes place, what is important is that information has been transmitted. According to Asemah, Anum and Edegoh (2013, p.18) information is central to all forms of human activity no matter the field, be it medicine, agriculture, tourism or engineering.

One of the oldest mainstream media that transmits information in modern human society is the print media (newspapers and magazines). The use of print mediated communication for socio-cultural, economic and political gratifications has been established in the field of journalism and communication for some time now (Okunna, 2002; Ottah, 2017). A school of thought in this area of social inquiry focuses not on what the communication media do to people but on what people do with the media messages and how people use such information 
Doi:doi.org/10.47851/naujocommed.v2i1.112

for satisfying their individual needs. Due to increasing global public health problems, researchers now focus on health communication in relation to the mounting campaigns to create public awareness for behavioural change for or against a particular issue in the society. The global Covid-19 pandemic has challenged the ability, capability and ingenuity of newspaper outfits to deal with the spread of the virus.

There has been series of studies to prove that audiences derive media utility mainly from the information, education and entertainment roles the mass media perform (Ganiyu, Mohammed, Ismail, 2017, Kakonge, 2012; Khodarahmi, 2009). As the fourth estate of the realm; they assume another position in-between the various organs of government. To this effect, they play watchdog roles and ensure normalcy in a democratic setting between the leaders and the followers.

It is imperative to understand that Nigerian newspapers wield considerable influence in the society as they serve as channels through which members of the society are informed, educated, enlightened and mobilised to take part in activities in the society. Newspapers have the power to direct public attention and chart the way in confronting certain issues. This is evident in the agenda-setting function of the mass media. Through its coverage, newspapers also perform the status conferral function. As such, newspapers' report on Covid-19 pandemic can confer status or credibility to its knowledge in such a way that members of the society are either encouraged to adopting the messages against the spread of the virus.

Over the years, newspapers have proven to have the capacity to create awareness, accelerate information flow and mobilise members of the society to take part in activities which the newspapers play up before them. The reactions of the public towards newspaper reports of issues in the society are very important. It becomes an evidence of how the messages were perceived and understood. How do the readers of Daily Sun, Vanguard and National Light newspapers react towards Covid-19 information from the medium of newspaper available in the form of knowledge to stem the spread of the virus? This is the problem that this study seeks to unravel.

\section{Origin of Coronavirus Disease (COVID-19)}

The novel Coronavirus tagged (COVID-19) is a viral infection. It is caused by a painful acute respiratory syndrome known as 2 (SARS-CoV-2). The virus emerged in Wuhan, China and spread around the world. According to Shereen, Khan, Kazmi, Bashir \& Siddique (2020), the virus is highly transmittable and pathogenic. The common origin and/ or transmissionof the novel Coronavirus to people or human beings is yet unknown. No withstanding, the wild firelike spread or transmission of Coronavirus from individuals was confirmed widely. Shereen et al. (2020), though, held that there was no clinically approved antiviral drug or vaccine available for use against COVID-19. However, a few broad-spectrum antiviral medications tested against Coronavirus in clinical trials, proved effective as they resulted in clinical recovery. Presently, there have been discoveries in the vaccines against Coronavirus such as COVAX used in Nigeria, AstraZeneca among others.

Approaching the end of 2019, Wuhan, a famous business city in China, had an outbreak of a novel Coronavirus. As early as the first fifty days the epidemic started, the disease killed over 18,000 and infected more than 70,000 people (Cui, Li \& Shi 2019). According to Cui, Li \& Shi (2019), the novel virus called COVID-19 by Chinese researchers is deadly compared to SRAS-CoV in 2003 that infected 8,098 individuals with a mortality rate of $9 \%$, across 2 
Doi:doi.org/10.47851/naujocommed.v2i1.112

countries in the world. On the other hand, the novel Coronavirus in 2019 infected 120,000 individuals with a mortality rate of $2.9 \%$, across 109 countries (Lai, Shih, Ko, Tang \& Hsueh 2019). The transmission rate of SARS-CoV-2 is found to be higher than SRAS-CoV. The reason, according to Lai, Shih, Ko, Tang \& Hsueh (2019), could be that genetic recombination event at $\mathrm{S}$ protein in the RBD region of SARS-CoV-2 might have enhanced its transmission ability.

Investigations have shown that those who had the infection earlier neither visited the seafood market nor consumed them as alleged in the reports. According to Ezebuenyi et al. (2020) the finding showed that the spread of virus was from individual to individual. In many nations of the world, the same mode of transmission was recorded (Phan, Nguyen, Luong, Nguyen, Nguyen \& Le, 2020; Riou \& Althaus, 2020). This mode of transmission from individual to another was as a result of close contacts with someone already infected with the virus, having being exposed to coughing, sneezing, respiratory droplets or aerosols. According to Phan, Nguyen, Luong, Nguyen, Nguyen \& Le, 2020; Riou \& Althaus (2020), these aerosols can penetrate the human body (lungs) through inhalation through the nose or mouth.

\section{Coronavirus Case in Nigeria}

The Coronavirus, first identified in Wuhan China in December 2019, has rapidly spread to almost every nation of the world. The disease is caused by a new and severe type of Coronavirus known as severe acute respiratory syndrome Coronavirus 2 (SARSCoV-2). The virus has been pronounced a pandemic by the World Health Organisation (WHO, 2020). This is because of the rate of morbidity and mortality caused by the infection has reached frightening proportion. As early as fifty days of the outbreak of the virus, confirmed cases rose to $1,603,428$ while those already dead got to 95,714 persons all over the world (Worldometers, 2020).

In Nigeria, towards the end of February 2020, we recorded an index case, when a citizen of Italy visited Nigeria on 27th February (Radio Nigeria, 2020). Thereafter, reports of confirmed cases rose to 288 with 51 people already discharged after treatment from in April 9 (NCDC, 2020). Presently, however, Nigeria has delved into the second wave of the pandemic, which is said to be more deadly than the first wave. This has resulted in many states of the federation recording more infections than before. Therefore, as at $12^{\text {th }}$ March 2021, Nigeria has recorded 159.933 cases, 2,001 deaths and 142,404 recoveries (Worldometer, 2021).

There have massive campaigns from various bodies that fought to stem the spread of the infection. Civil society organizations, government agencies and other critical stakeholders mounted sensitization campaigns encouraging the citizens to practice good hygiene and making sure they keep a distance from one another. Both broadcast media and the print have been deployed in the campaigns. A lot of safety measures were put in place at various points. People were encouraged to self-isolate. There was indiscriminate suspension of public gathering above 50 persons. People were urged to stay at home (Ewodage, 2020).Various containment measures were equally introduced in our country such as closure of national borders, airports, schools, worship centers among other public places (Radio Nigeria, 2020; Olatunji, 2020). The government of the federation and various state governments have been involved in distributing food stuff, money and materials as palliatives to cushion the effects of Coronavirus in the nation. Even, well-to-do individuals have also given out palliatives to the needy and less - privileged. Some of them donated money to the various governments to 
Doi:doi.org/10.47851/naujocommed.v2i1.112

assist in providing the enabling ground to combat the spread of the virus as well as the effects in our land (Oyekanmi, 2020).

Similarly, institutions, companies and organizations have paid their dues in contributing palliatives to person and government at all levels. As a consequence, the Nigerian economy has been battered in the face of rampaging Coronavirus disease. The spread of the novel Coronavirus (COVID-19) in Nigeria continues to record significant increase as the latest statistics provided by the Nigeria Centre for Disease Control reveal Nigeria as at 12th of March 2021, has 159.933 cases, 2,001 deaths and 142,404 recoveries (Worldometer, 2021).

\section{The Importance of Framing: Between Issue Reportage and Public Health Promotion}

The mass media are windows to the world through which people learn about the world outside their country. According to Park (2003) the window does not show the world as it is. People only see the world within the frame of the window. If the frame of the window is too small, people will only see a small part of the world. The importance of framing in message positioning to the readers of such messages cannot be over-emphasized (Reese, 2001). In journalism practice, framing means the way the media see a thing or the way they want the audience to see a story, event of happening. This, the mass media achieve by making the news angles salient, based on selection of words, language among other features, often to protect editorial interests or ownership philosophy (Yusha'u, 2011). This process also has significant relevance to the way people interpret and react to the entire story. Using framing4to influence audience permeates almost all media reports to foster and trill the overwhelming media audience to align with the interest celebrated by the media.

The outbreak of Coronavirus, as global concerns since late 2019, makes banner headlines in the world media and perhaps formed news angle of audience attraction in the Nigerian media. Various sections of the media have contributed literature on the novel Coronavirus. Through frequent reportage on the disease, the broadcast, print and social media platforms have deployed various prime time spaces to health talks especially as it concerns COVID-19 pandemic. Both national and local media outfits have quality newscast on the novel Coronavirus issues than ever before.

Though, there have been series of relevant academic studies and research efforts on media framing conducted on public health issues (Adeyanju \& Oriola, 2010) attract but it is expected that the COVID-19 pandemic experience will attract more academic endeavours. The purpose for which the media send a message to the audience most often determines the interest that the media are bound to protect (whether overtly or covertly) and that invariably influence how media frame such news item. Finding the relationship between the variables will lay a solid foundation for establishing how the public perceive and respond to the way media present (framed) news stories on health issues most especially Coronavirus outbreak. The way issues are presented in the news guides how people perceive the message and how they conceptualized possible solutions to the problems presented or take to suggestions made.

The public perceptions of news items other than health issues might not be applicable to media reportage of health issues if it could be established that the essence of reporting the news items is for different interest. Smith (2014) agrees that "....descriptive analyses of the form of news reports of health topics can provide important insights into the way people understands issues in addition to how policy initiatives may fare." Going by the analyses of previous studies on public health issue (Atiq, 2011; Niedermeir, 2012; Sobel, 2014; Thuesen. 
2010), media involvement is well noticed in terms of coverage and campaigns. Nevertheless, media impact could be measured along the public sensitisation and behavioural influence not to cure but to stem the spread of the virus.

The major aim of this study is not to know how much the media of mass communication partake on issues of health in relation to the ways information is reported. This is because several studies (Catalán-Matamoros, 2011; Cavaca et al., 2015) have been carried out on the matter from time to time. The volume of information on health issues despite having a holistic approach in creating awareness on public health does not summarily dealt with all the aspects on messages which are considered salient.

\section{THEORETICAL FRAMEWORK}

\section{The Agenda Setting Theory}

The agenda setting theory was postulated by McCombs and Donald L. Shaw in the year 1972. The major assumption, which the theory presents, is to set the agenda for what issues the people considered important for discuss at a given time. Based on the above view, a relationship therefore exists between what the media presents as message and the importance, which the public gives to news and happenings. Again the theory equally states, the media do not possess the ability to determine what the society actually thinks, but they do possess the ability to determine what the society thinks about. The above can be linked to the work of Benard-Cohen (1963) cited in Ezebuenyi (2018) who notes that the press "may not be successful much of the time in telling people what to think, but it is stunningly successful in telling its readers what to think about" (p. 120). Supporting the above, Baran and Davies $(2009$, p. 279), posit that "the press is significantly more than a purveyor of information and opinion.

The theory is relevant to this study, in that the mass media of communication sets the agenda for issues that the public see as salient to them. The issues highlighted in the newspapers would help to build public perception, understanding and the opinion they would form on the novel COVID-19 pandemic. More so, the agenda-setting theory is significant to the study to the extent that the agenda set by the press can play a vital role in directing the audience towards understanding the how novel Coronavirus can be contained without further spread.

\section{METHODOLOGY}

The mixed method was used as the research design. The method was quite apt in the study as it entails using both the survey and content analytical methods in obtaining an authentic and dependable result. The two methods complemented each other so that a more reliable result was achieved by the study. This study is limited to Awka Metropolis. It is also limited to readers of newspapers (Daily Sun, Vanguard and National Light) purposively selected for the study. The selection of the three dailies is based on their availability, reach and popularity among the respondents. The period of the study ranges from $1^{\text {st }}$ February, 2020 to $30^{\text {th }}$ November, 2020. This was the period after an index case was recorded in Lagos State to when the lockdown by different countries' government has eased up with the resumption of International flights.

\section{Population of the Study}

For the survey method, population of the study is the 371,038 projected population of Awka Metropolis extrapolated from the 2006 population census in Nigeria. For the content analysis, the population of study was the 88 editions of newspapers gathered from each of the thre 
Volume 2 Number 1 Jan-Mar Issue

Doi:doi.org/10.47851/naujocommed.v2i1.112

national dailies under examination which are Daily Sun, Vanguard and National Light. These daily newspapers were purposively selected for this study on the bases of convenience. It is the 909 editions of the three newspapers selected between February $1^{\text {st }}$ and $30^{\text {th }}$ November 2020 that constitute the population for the study.

Table 1: Population of Study Content Analysis

\begin{tabular}{|c|c|c|c|}
\hline 2020 & $\begin{array}{c}\text { February } \\
\text { March } \\
\text { April } \\
\text { May } \\
\text { June } \\
\text { July } \\
\text { August } \\
\text { September } \\
\text { October } \\
\text { November }\end{array}$ & $\begin{array}{l}28 \\
31 \\
30 \\
31 \\
30 \\
31 \\
31 \\
30 \\
31 \\
30\end{array}$ & 303 \\
\hline Total $=1$ year & 10 months & 44 weeks & $303 \times 3=909$ \\
\hline
\end{tabular}

\section{Sample Size and Sampling Techniques}

The sample size for the study is 399. This was determined using the Taro Yamani's, (1973) sample size formula and supported by Wimmer and Dominick (2011), who certified that the sample size is adequate for a study of this magnitude. The purposive sampling technique was used to select the samples.

For the content analysis method, the researcher used the simple random sampling technique to select two editions of the three select newspapers (Tuesdays and Thursdays) of every week, for a total of 44 weeks: (6 editions x 44 weeks $=264$ ). This amounted to a sample size of 264 editions.

Table 2: Number of Editions each of the three Newspapers was Allocated

\begin{tabular}{lc}
\hline $28^{\text {th }}$ February to $30^{\text {th }}$ November 2020 & Number of Editions of the Newspapers \\
\hline Daily Sun & 88 \\
Vanguard & 88 \\
National Light & 88 \\
Total & 264 \\
\hline
\end{tabular}

Tabular description of number of newspaper editions by the three national dailies

\section{Unit of Analysis}


The unit of analysis in this study is the identification of the frames, (number of frame pattern used in the coverage). To examine the newspaper framing of COVID-19 pandemic, seven patterns of frames were analysed. The frames are:

"Causes and transmission frame," "Treatment \& control/Containment frame," "Fear and death frame," "Sabotage/Conspiracy frame," "Government/Political influence frame," "Effect frame" and "Rumour/misinformation frame."

\section{Content Category}

For this study, the content category is the different ways the patterns of frames were used in the Coronavirus stories by the newspapers under study. The content categories are:

1. Straight news reports: Sometimes referred to as hard news reports. It is news that consist of facts without embellishment;

2. Feature stories: Human interest articles that focus on a particular news story;

3. Editorials: Expositions by editors of selected newspapers that give an opinion on a certain news story;

4. Opinion articles: People's opinion on a news story from their personal point of view.

\section{METHOD AND TECHNIQUE OF DATA COLLECTION, PRESENTATION AND ANALYSIS}

The instruments used in collecting data for the survey method is the questionnaire while the coding system was used for the content analysis. Both methods used the qualitative analysis in analyzing the data gathered in the study. The data generated in the study were manually counted, coded and presented in simple frequency distribution tables. Answers to research questions were expressed in simple percentages.

\section{DATA PRESENTATION AND ANALYSIS}

\section{Research Question One:}

What are the patterns of frames used in covering the novel Coronavirus in Nigerian newspapers?

Table 3: Analysis of frames used in reporting stories on the Covid-19 in the select newspapers

\begin{tabular}{|c|c|c|c|c|c|c|c|c|}
\hline $\begin{array}{l}\text { News/ } \\
\text { Papers }\end{array}$ & $\begin{array}{l}\text { Cause/ } \\
\text { Transm } \\
\mathrm{i} \\
\text { ssion } \\
\text { frame }\end{array}$ & $\begin{array}{l}\text { Treatment/ } \\
\text { Containmen } \\
\mathrm{t} \\
\text { Frame }\end{array}$ & $\begin{array}{l}\text { Fear/ } \\
\text { Deat } \\
\mathrm{h} \\
\text { frame }\end{array}$ & $\begin{array}{l}\text { Sensitiz } \\
\text { a } \\
\text { tion } \\
\text { frame }\end{array}$ & $\begin{array}{l}\text { Effec } \\
t \\
\text { frame }\end{array}$ & $\begin{array}{l}\text { Govt./Pol } \\
\text { Frame }\end{array}$ & $\begin{array}{l}\text { Rumuor } \\
\text { / } \\
\text { Misinfor } \\
\text { mation } \\
\text { frame }\end{array}$ & $\begin{array}{l}\text { Tota } \\
1\end{array}$ \\
\hline $\begin{array}{l}\text { Daily } \\
\text { Sun }\end{array}$ & 15 & 14 & 15 & 10 & 14 & 8 & 12 & 88 \\
\hline $\begin{array}{l}\text { Vanguar } \\
\text { d }\end{array}$ & 13 & 13 & 16 & 11 & 13 & 9 & 16 & 88 \\
\hline $\begin{array}{l}\text { National } \\
\text { Light }\end{array}$ & 12 & 15 & 15 & 14 & 12 & 10 & 10 & 88 \\
\hline Total & 40 & 42 & 46 & 35 & 39 & 27 & 38 & 264 \\
\hline
\end{tabular}


Doi:doi.org/10.47851/naujocommed.v2i1.112

Out of the 399 copies of questionnaire distributed to residents of Awka Metropolis, 386 were returned and found usable amounting to $96.7 \%$ response rate and $3.3 \%$ mortality rate. The respondents were literate adults aged 18 years and above.

\section{Research Question Two:}

What is respondents' frequency of exposure to newspaper reports of COVID-19 pandemic?

Table 4: Assessment of frequency of exposure to COVID-19 reports

\begin{tabular}{lcr}
\hline Respondents & Frequency & Percentage \\
Very frequently & 109 & 28.2 \\
Frequently & 125 & 32.4 \\
Sometimes & 86 & 22.3 \\
Rarely & 41 & 10.6 \\
Very rarely & 25 & 6.5 \\
Total & 386 & 100
\end{tabular}

Analysis of data in Table 4 above shows that 109 representing 28.2 percent of the respondents answered 'very frequently' when asked to indicate their frequency of exposure to stories on COVID-19 pandemic, 125 or 32.4 percent answered 'frequently', 86 or 22.3 percent answered 'sometimes', 41 or 10.6 percent answered 'rarely', while 25 or 6.5 percent answered 'very rarely'. This is an indication that more than two-thirds majority of the respondents have high frequency of exposure to stories on COVID-19 pandemic.

\section{Research Question Three}

Does the way newspapers report COVID-19 pandemic creates the desired awareness against the spread of the virus.

Table 5: Assessment of whether newspaper reports of COVID-19 pandemic creates awareness against the spread of the virus

\begin{tabular}{|c|c|c|}
\hline R e s p o s & Frequency & Percentage \\
\hline Y e s & 267 & 69.2 \\
\hline N o & 32 & 8.3 \\
\hline Don't know & 87 & 22.5 \\
\hline To t a & 386 & 100 \\
\hline
\end{tabular}

Analysis of data in Table 5 shows that 268 representing 69.2 percent of the respondents answered "yes" when asked to indicate whether the way newspapers report COVID-19 pandemic creates the desired awareness against the spread of the virus, 32 or 8.3 percent answered "no" while 87 or 22.5 percent had no opinion on the question. This means that more than two-thirds majority of the respondents believed that newspaper reports of COVI19 pandemic creates the desired awareness against the spread of the virus. 
Volume 2 Number 1 Jan-Mar Issue

Doi:doi.org/10.47851/naujocommed.v2i1.112

\section{Research Question Four}

What is respondents' perception of news stories on COVID-19 pandemic?

Table 6: Assessment of respondents' perception of news stories on Covid-19

\begin{tabular}{lcc}
\hline Respondents & Frequency & Percentage \\
\hline Very educative & 96 & 24.9 \\
Educative & 128 & 33.2 \\
Fairly educative & 92 & 23.8 \\
Not educative & 43 & 11.2 \\
Don't know & 27 & 6.9 \\
Total & 386 & 100 \\
\hline
\end{tabular}

Analysis of data in Table 6 shows that 96 representing 24.9 percent of the respondents answered "very educative" when asked their perception of news stories on COVID-19 pandemic, 128 or 33.2 percent answered "educative", 92 or 23.8 percent answered "fairly educative", 43 or 11.2 percent answered "not educative" while 27 or 6.7 percent had no opinion on the question. This means that more than two- thirds majority of the respondents perceive news stories on COVID-19 pandemic. This is also an indication that majority of the respondents accede to have positive perception on how news stories on COVID-19 pandemic are framed.

\section{Research Question Five}

Does the way the newspapers select, package and present stories (frame) on COVID-19 pandemic influence respondents' views about the virus?

Table 7: Assessment of whether the way news stories on COVID-19 pandemic were reported influenced respondents' views about the virus

\begin{tabular}{lcc}
\hline Respondents & Frequency & Percentage \\
\hline Strongly agreed & 119 & 30.8 \\
Agreed & 115 & 29.8 \\
Neutral & 86 & 22.3 \\
Disagreed & 41 & 10.6 \\
Strongly disagreed & 25 & 6.5 \\
Total & 386 & 100
\end{tabular}

Analysis of data in Table 7 shows that 119 representing 30.8 percent of the respondents answered "strongly agreed" when asked to indicate whether news stories on COVID-19 pandemic influence respondents' views about the virus, 115 or 29.8 percent answered "agreed", 86 or 22.3 percent had no opinion on the question and therefore indicated "neutral", 41 or 10.6 percent answered "disagreed" while 25 or 6.5 percent answered "strongly disagreed'. This is an indication that more than two-thirds majority of the respondents accede to news stories on COVID-19 pandemic having influence on readers' views on the virus.

\section{DISCUSSION OF FINDINGS}

The study investigated the influence of newspaper framing of COVID-19 pandemic on readers' perception of the virus. From research question one, the finding shows that seven patterns of frames were used in reporting stories on Covid-19. This is evident in Table 
the study where frames were recorded. From research question two, the finding revealed that a more than two-thirds majority of the respondents have high frequency of exposure to stories on COVID-19 pandemic. This finding reinforces an earlier submission by Weaver, McCombs \& Shaw (2004) that there is a correlation between the level of importance ascribed to issues in the media and the priorities of the public. In the same manner, Sobel (2014) held that frame had consistency for its logically articulated elements from the audience's worldview (experiential commensurability), cultural context (narrative fidelity) and existing problems (empirical credibility).

From research question two, the finding showed that a more than two-thirds majority of the respondents believed that newspaper framing of COVI-19 pandemic creates the desired awareness against the spread of the virus. This finding supports an earlier observation by Huang (2010), who posits that some issues given their level of importance to the audience at a point left the media with no option than to give necessary attention to them, adding that the way the media manage information on health issues, usually points to awareness on public health as well as their sensitivities to the problems and demands on health.

From research question three, the finding showed that majority of the respondents accede to have positive perception on how news stories on COVID-19 pandemic are framed. This finding is in tandem with result of an earlier study carried out by Yusha'u (2011), who held that framing, which describes the way the media see a thing or the way they want the audience to see a story, event of happening is achieved by making the news angles salient, based on selection of words, language among other features, often to protect editorial interests or ownership philosophy. This process according to him has significant relevance to the way people interpret and react to the entire story.

From research question four, the finding showed that more than two-thirds majority of the respondents accede that news stories on COVID-19 pandemic have influence on readers' views on the virus. This finding also supports an earlier observation by Thuesen (2010), who asserts that media involvement is well noticed in terms of coverage and campaigns. Nevertheless, media impact could be measured along the public sensitisation and behavioural influence not to cure but to stem the spread of the virus.

\section{CONCLUSION}

The study has provided evidence into the differences in newspaper reporting and framing of the novel Coronavirus, showing the influence on readers' perception of the virus A significant contribution of this study is the analysis of the way frames could contribute to the understanding of the role the media play in audience perception of a phenomenon. The study has also stressed the fact that framing has the ability to influence audience perception of a particular event. The framing of the novel Coronavirus enjoys favourable comments in the media. Also worthy of note is that framing of news stories about the novel Coronavirus is much more influenced by the social responsibility of the media than economic motive of the journalists to compete for readership by picking news angle that arouses readers' interests in order to sell more copies in the keen competitive media market. It is also important to note that news stories used in covering the novel Coronavirus were positive or favourable thus supporting the fact that the coverage is directed towards finding solutions to the problem of the novel Coronavirus.

\section{RECOMMENDATIONS}


Doi:doi.org/10.47851/naujocommed.v2i1.112

Based on the findings from this study, it is recommended that the Nigerian press should endeavour to select appropriate news angles in reporting public health stories to stem the tendencies of creating rumours and misinformation. This also has the benefit of causing the polity to trust the media in their interpretations of health situations. The study also recommended that further studies be carried out to ascertain whether factors such as already existing belief and understanding of a phenomenon and not framing of news stories in the media is what influence public perception. It is also imperative to carry out a study on whether the way other media platforms frame stories on an issue can influence the public perception of such an issue. This is because most of the previous studies have limited their analysis of manifest content categories to frequency, prominence, depth and nature of coverage. This study notes that these categories are not exhaustive.

How do the media audience perceive the media framing of the novel Coronavirus stories?; What impact do the Coronavirus framed stories have on the attitudinal and behavioural change of the media audience?; and are there relationships between media framing of Coronavirus stories and the early containment of the outbreak in Nigeria? These are some of the questions still demanding for research analyses to verify, ascertain and establish the relationship between media framing of health issues, the public perceptions and reaction to it and the effect of the relationship between them.

\section{REFERENCES}

Abubakre, F. (2015). Media coverage and influence of 2015 presidentialelection campaigns on voting behaviour of 3members of staff of the University of Ilorin, Unpublished PhD Thesis, University of Ilorin

Adeyanju, C. T., \& Oriola, T. (2010). 'Not in Canada': The non-Ebola panic and media misrepresentation of the black community. African Journal of Criminology and Justice $\quad$ Studies, 4(1), 32-54.

Asemah, E. S., Anum, V. \& Edegoh, L. O. N. (2013). Radio as a tool for rural development in Nigeria. Prospects and challenges. International Journal of Arts and Humanities, 2 (1), 2011: pp.17-35 Association for Educational Communication and Technology. Available at www.aect.org. Accessed 22 August, 2019.

Atiq, E. (2011). Crisis communication in the context of the pakistan floods 2010. In M. Löffelholz\& A. Schwarz (Eds.), Working papers of the International Research Group on Crisis Communication (Vol. 1). Ilmenau, Germany: Ilmenau University of Technology /Department of Media Studies. 4

Baran, S. J. and Davis, D. K. (2012). Mass Communication Theory: Foundation, Ferment and Future ( $3^{\text {rd }}$ Ed). Belmont: Wadsworth/Thompson.

Catalán-Matamoros, D. (2011). The role of mass media communication in public health: INTECH. Open Access Publisher.

Cavaca, A. G., Vasconcellos-Silva, P. R., Ferreira, P., \&Nunes, J. A. (2015). Between evidence and negligence: coverage and invisibility of health topics in the Portuguese printed media Ciencia\&SaudeColetiva, 20(11), 3569-3580. 
Doi:doi.org/10.47851/naujocommed.v2i1.112

Cornelissen, G., Pandelaere, M., Warlop, L., \&Dewitte, S. (2008). Positive cueing:

Promoting sustainable consumer behavior by cueing common environmental behaviors as environmental. International Journal of Research in Marketing, 25(1), 46-55.

Cui, J., Li, F., Shi, Z. (2019). Origin and evolution of pathogenic coronaviruses. Nat Rev Microbiol 2019, 17 (3), 181-92.

Ewodage, R. (March 2020). COVID-19: How we plan to implement social distancing in Lagos markets, transport system - Sanwo-Olu. Retrieved from https://www.channelstv.com/2020/03/22/covid-19-how-we-plan-to-implement-socialdistancing-in-lagos-markets-transport-system-sanwo-olu/ (5th August, 2020)

Ezebuenyi, E.E. (2018). Newspaper framing of health Millennium Development Goals in Nigeria. Mass Media Review, An International Journal of Mass Communication. Vol. 2, $\quad$ No 2. Pp.107 - 119.

Ezebuenyi, E.E., Ekwunife, R.O. \& Nweke, F.C. (2020). Critical assessment of the ambivalent potentials of social media use in COVID-19 pandemic campaigns. Nnamdi Azikiwe University Journal of Communication and Media Studies, Vol. 1, No.1 (2020).

Ganiyu, M.A., Mohammed, R. and Ismail, A. (2017). Effective media involvement in flood disaster management in Nigeria: Pressing problem and recommendations. Asian

Pacific Journal of Education, Arts and Science, Vol. 4 No. 1 pp. 21-30.

Huang, H. P. (2010). Frame-Rich, Frame-Poor: An Investigation of the Contingent Effects of Media Frame Diversity and Individual Differences on Audience Frame Diversity. International Journal of Public Opinion Research, 22(1), 47-73.

Kakonge, J.O. (2012). Improving the Role of the Media in Disaster Management for Africa. Global Policy. Retrieved from

http://www.globalpolicyjournal.com/blog/21/06/2012/improving-role-media-disastermanagement-africa. (Accessed on August 21, 2019).

Khodarahmi, E. (2009). Media relations. Disaster Prevention and Management.Vol.18, No. 5.2009.Emerald.

Lai, C., Shih, T., Ko, W., Tang, H., Hsueh, P. (2019). Severe acute respiratory syndrome coronavirus 2 (SARS-CoV-2) and coronavirus -2019 (COVID-19)

Niedermeir, F. (2012). Facebook as an instrument of strategic crisis communication: A content analysis of the nestlé palm oil crisis. In M. Löffelholz\& A. Schwarz (Eds.), Working papers of the International Research Group on Crisis Communication (Vol. 2). Ilmenau, Germany: Ilmenau University of Technology/Department of Media Studies.

Nigerian Centre for Disease Control (2020). Covid-19 Update in Nigeria: Retrieved from 2020: 
Nwabueze, C. and Ezebuenyi, E (2019). Newspaper framing of Biafra agitation under Buhari's administration and its influence on public support for the struggle. African Journalism Studies. https://doi.org/10.1080/23743670.2019.1570296.

Nwammuo, A.N., Edegoh, L.O.N. \& Iwok, U. (2015). Nigeria press coverage of the 2015 elections: What has ownership got to do with it? International Journal of African and Asian Studies, Vol. 14. www.iiste.org. Retrieved on September 23, 2017

Okoro, N. and Odoemelam, C.C. (2013). Print media framing of BokoHaram insurgency in Nigeria: A content analytical study of The Guardian, Daily Sun, Vanguard and

Thisday newspapers Humanities and Social Sciences. www.iiste.org ISSN 2222-1719 (Paper) ISSN 2222-2863 (Online)Vol.3, No.11, 2013

Okunna, C.S. (2002). A Quick Look at Development Communication, in OkunnaC.S.(Ed), Teaching Mass Communication: A Multi-Dimensional Approach, (pp. 293-302). Enugu: New Generation Books.

Ottah, G. A. (2015). Creative advertising. Lokoja: Onaivi Publishers.

Ottah, G. A. (2017). Impact of Radio Kogi’s Flood Disaster Awareness Campaign on Residents of Ibaji Local Government Area of Kogi State, Nigeria. International Journal of Arts and Humanities (IJAH) Ethiopia Vol. 6(3), S/No 22, July, 2017: 8097

Oyekanmi, S (19 July, 2020). Coronavirus COVID-19 updates in Nigeria. https://www.worldometers.info>nig... (29th July, 2020).

Park, J. (2003). Contrasts in the coverage of Korea and Japan by US television networks: A frame analysis. Gazette, 145.

Phan, L.T., Nguyen, T.V., Luong, Q.C., Nguyen, T.V., Nguyen, H.T, Le, H.Q. (2020). Importation and human-to-human transmission of a novel coronavirusinVietnam. $N$ Engl J Med 2020.

Radio Nigeria. (March 2020). 3President Buhari urges caution, not fear over Covid_19 (Full text). Retrieved from https://www.radionigeria.gov.ng/2020/03/19/presidentbuhariurges-caution-not-fearover-covid_19-full-text/ (5th August, 2020)

Reese, S. D. (2001). Prologue - framing public life In S. D. Reese (Ed.), Framing public life: Perspective on media and our understanding of the social world. Mahwah: Lawrence Erlbaum.

Riou, J., Althaus, C.L. (2020). 4The Pattern of first human-to-human transmission of Wuhan 2019 novel coronavirus (2019-nCoV), December 2019 to January 2020. Eurosurveillance. 2020; 25(4). 
Doi:doi.org/10.47851/naujocommed.v2i1.112

Smith, K. C. (2014). News media analysis: Influence on community health behaviours and practices. In J. Burke \& S. Albert (Eds.), Methods for Community Public Health Research: Integrated and Engaged Approaches. New York: Springer Publishing Company.

Sobel, M. R. (2014). Chronicling a crisis: media framing of human trafficking in India, Thailand, and the USA. Asian Journal of Communication, 24(4), 315.

Thuesen, M. (2010). Crisis communication - in organisational crises with intense media attention. (Master of Arts in Corporate Communication), Aarhus School of Business. 1

Weaver, D., McCombs, M. \& Shaw, D.L. (2004). Agenda-setting research: Issues, attributes, and influences. In L.L. Kaid (Ed.) Handbook of Political Communication Research. Mahwah, NJ: Lawrence Erlbaum Associates.

Wimmer, D. R., \& Dominick, J. R. (2011). Introduction to mass communication research Canada: Wadsworth.

World Health Organisation (2020). Laboratory testing for coronavirus disease 2019 (COVID19) in suspected human cases: interim guidance, 2 March 2020. World Health Organization, 2020.

Worldometers (April 2020). Coronavirus Update (Live). Retrieved from https://www.worldometers.info/coronavirus/ (4th August, 2020)

Worldometers (February 2021). Coronavirus Update (Live). Retrieved from https://www.worldometers.info/coronavirus/ (14th March, 2020)

Yusha'u, M. J. (2011). News framing of the 'Detroit Bomber' in the Nigerian press.Global Media and Communication, 7(3), 281-286. 